\title{
HEAT REQUIREMENT OF POMEGRANATE FRUIT: A CASE STUDY ON SHISHE-KAB CULTIVAR
}

\author{
Mina MOHAMMADIAN MOGHADDAM ${ }^{1}$, Farid MORADINEZHAD ${ }^{1}$, \\ Mehdi KHAYYAT ${ }^{1}$
}

\author{
*E-mail: moghaddam.mina222@gmail.com
}

Received: Oct. 27, 2019. Revised: Dec. 08, 2019. Accepted: Dec. 13, 2019. Published online: Dec. 20, 2019

\begin{abstract}
The aim of this study was to determine growing degree day (GDD) for pomegranate fruit Shishe-Kab cultivar and study the phonological stages of fruit from bloom to harvest. A completely randomized block design was carried out on the research orchard of the Faculty of Agriculture, University of Birjand, 2017. During the May to October, the diameter and length of the fruits and calyx were recorded using the non-destructive method by a digital caliper on the tree. Next fruit samples were randomly taken from the trees to determine fresh and dry weight. Furthermore, by using the metrological data, the thermal requirement based on the growth degree day (GDD) has been determined from April until harvest day. The effective heat requirement for Shishe-Kab cultivar that was calculated from blooming to reach maturity was 2560.95. The highest cumulative temperature was recorded in the commercial harvest date. By receiving this degree day, fruit reached the highest fresh and dry weight, length and also diameter at the end of growing season. The results indicated that all fruit
\end{abstract}

characteristics significantly increased from the first recording day till the end, except the ratio of fruit length to diameter. A slight decrease in growth rate was presented in fruit diameter and length, which was concomitant with their seed hardening. Results showed that calyx diameter and length of pomegranate fruit has a slow continues liner growth pattern, fruit length and diameter exhibited a double sigmoid growth curve, while the fresh and dry weight followed a single sigmoidal curve. By determining the fruit growth pattern under climatic conditions, it is possible to determine the length of growing season and the critical stages of growth for proper management in the garden.

Keywords: fruit growth curve; growing degree day; non-destructive method; phonological stages; temperature.

\section{INTRODUCTION}

Pomegranate (Punica granatum) is native to Iran and the surrounding area and is one of the oldest known

\footnotetext{
${ }^{1}$ Department of Horticultural Science, College of Agriculture, Birjand University, Birjand, Iran
} 
edible fruits (Pekmezci and Erkan, 2003). Pomegranate is an invaluable fruit and the source of secondary products, such as tannins, alkaloids, anthocyanin and antioxidants (Kumar et al., 2017). It is tolerant to drought and salt, so widely cultivated in dry, hot areas of the world (Korkmaz et al., 2016). Since ancient times, the pomegranate has been considered as a "healing food" with many beneficial effects in several human diseases (Vidal et al., 2003).

In growth stages, a chain of physiological, biochemical and structural process result to changes in size, color and flavor of pomegranate fruit (Moing et al., 1998; Nunes et al., 2009). Physicochemical and textural properties, like size, color, juiciness and taste are influenced by genetics and environment, which widely different among pomegranate cultivars (Holland et al., 2009; Jalikop, 2007; Martinez et al., 2006).

Cracking, aril paleness and sun burning are some of pomegranate cultivation problems, which causes a lot of damage every year (Génard and Bruchou, 1993; Gozlekci and Kaynak, 2000). Therefore, knowing how fruit grows, morphologically and physiologically changes from flowering to ripening would help to manage the farm properly. Failure to meet the climatic requirements of tree crops makes orchards not enough productive to pay off the investments needed for their establishment (Luedeling et al., 2009).

Since the fruit formation, ripening, maturity and their quality are affected by cultivar, region's climate etc (Özkan, 2002; Rajasekar et al., 2012), it is necessary to study these factors for knowing the plant's physiology and high crop production (Schaffer and Andersen, 1994; Wien, 1997). To investigate the effect of cultivar on fruit grow, Moosavi et al. (2009) studied the fruit grow pattern of nine Asian pears under the Tehran climatic condition. They recognized a complete simple sigmoid for all nine cultivars, but the period of time for each of the growing phases was different. The differences in climate between persimmon production areas caused a wide variation in the growth of persimmon fruit, maturity and quality at harvest time (Candir et al., 2009; Mowat et al., 1996). Varasteh et al. (2006) studied the physicochemical characteristics of some commercial pomegranate cultivars grown in different regions of Iran to develop an index for cultivar selection for pomegranate production. They observed a wide variation of the characteristics of studied cultivars that can be used to cultivar selection in pomegranate production and breeding programs in the future.

Primarily, among the climatic factors, temperature variations are more important due to the effect on seed germination, growth, flowering, fruit formation and ripening of horticultural crops (Egea et al., 2003; Valentini et al., 2001). Temperature (high and low) is one of the most limiting environmental factors for growth and production of fruit and it is different for each species. Studying the ecological conditions, like heat 
sum during the growing season, is essential to choose the most suitable cultivars and product high-quality fruit (Ikinci et al., 2014). Determining the thermal requirement in predicting management times is important (Qashqai et al., 2017). Also, it would provide an assessment of the performance and adaptation of genotypes in certain growing areas (Rea and Eccel, 2006).

Due to the effect of different environmental factors, especially temperature on growth, development, quality and the date of harvesting fruit, study the annual calendar of plant biological events, such as budburst and swelling, shoot growth and increments in trunk diameter, root dynamics as well as reproductive growth, like flower initiation, fruit set and maturity seems to be useful. It would help growers to schedule specific fertilization and the application of hormonal or phytosanitary products (Bleiholder et al., 1989). It has been reported that high temperatures during the early period, reduced the development of fruit with the low chilling requirement (Wert et al., 2009).

Cangi et al. (2008) investigated the effective heat summations requirement for maturation of some grape cultivars grown. In another study the phonological stages of early-maturing peach trees were described and the heat requirement of each stage was calculated as growing degree hours (GDH) and growing degree days (GDD) (Mounzer et al., 2008). Soloklui et al. (2017) studied the chilling and heat requirements of 20 Iranian pomegranate cultivars and their correlations with geographical and climatic parameters, as well as tree and fruit characteristics. A range of variation in heat requirements from 4096 to 7928 growing degree hour (GDH) was observed among cultivars. Also, Ikinci et al. (2014) determinated heat requirements and effective heat summations of some pomegranate cultivars grown in southern Anatolia, Turkey. However, no information is available about the heat requirement for Shishe-Kab pomegranate cultivar.

Therefore, the objective of this study was to describe the growth pattern of pomegranate fruit ShisheKab cultivar and to calculate the thermal requirement that helps predict the time to reach each phonological stage of fruit grow and development.

\section{MATERIAL AND METHODS}

This study was carried out in the research orchard of the Faculty of Agriculture, University of Birjand in 2017. The Shishe-Kab cultivar has delicious fruits with high marketability and suitable for long storage and export. Fruits have a thick peel, long calyx and low aril percentage (Ebtedaei et al., 2016). Trees irrigated at 10 day intervals and NPK fertilizer applied tree times during the growing season (May, June and July with one month interval). All the recommended cultural practices were kept uniform for all trees during the entire course of the investigation.

The non-destructive method was used to study fruit growth and development (Arzani, 1994). In this 
method, 18 fruit samples were randomly selected and labeled and then the diameter and length of the fruits and calyx were measured on the tree until harvest time. Observations were made during early in May to mid-October. The records were taken on April 26, May 3, 10, 14, 20, 31, June 10, 21, July 6, 16, September 6, 16, 26 and October 5, using a digital caliper. Also, five fruit were harvested randomly in each time for determining the fresh and dry weight. The thermal requirement based on the growth degree day (GDD) was calculated using the following formula (1).

$$
\mathrm{GDD}=(T \max +\mathrm{T} \min ) / 2-\mathrm{T} \text { base }
$$

where, $T \max$ is daily maximum temperature, $\mathrm{T} \min$ is daily minimum temperature and $T$ base is the base temperature for pomegranate growth (Richardson et al., 1975). The lowest temperature that metabolic processes result in a net substance gain in biomass and also required for bud swelling considered as $\mathrm{T}$ base. The base temperature is $10^{\circ} \mathrm{C}$ for pomegranate (Sitte et al., 1999; Jackson, 1999 b).

Maximum and minimum daily air temperatures $\left({ }^{\circ} \mathrm{C}\right)$ values (data) were collected from Birjand meteorological station during April to October for the 2017 growing seasons. The experiments were conducted using a completely randomized block design with three replicates that contain six samples for each replication. Six trees were used per replication and totally 18 trees for the experiment.

Obtained data were analyzed by GenStat (Discovery Edition, Version 9.2, 2007, VSN International Ltd., UK) and mean values were compared at the level of 5\% probability according to LSD test. Data presented as means $\pm \mathrm{SE}$.

\section{RESULTS AND DISCUSSION}

The different phonological stages of Shishe-Kab cultivar evaluated based on growing degree day (GDD). The heat requirements are also presented as GDD, accumulated from flowering to harvest time (Table 1). The results indicate that by getting close to the end of the growing season and approaching the harvest time, the cumulative temperature increased and the highest rate was recorded in the commercial harvest date. The effective heat requirement for Shishe-Kab cultivar that calculated from April 26 to reach maturity was 2560.95, which has been obtained during 175 days. The highest GDD was associated with the highest fresh and dry fruit weight, fruit and calyx length and also fruit diameter. Our results were similar with the Barati (2017) results on Berberies vulgaris L. In another study, Weaver (1976) calculated the required heat units based on the growing degree day from bloom to reach maturity for table grape. Early grapes required about 1600 degree days to mature, while the late ones at least 3500 degree days. In addition, Ikinci et al. (2014) determined the heat requirement of three pomegranate cultivars from bud swelling to leaf fall. They used the same method to calculate the GDD for 'Hicaznar', 'Suruc', and 'Katirbasi', under the same environmental conditions. They stated that GDD was approximately 2800-3300. The maximum heat requirement from open flowering to fruit ripening observed in 
'Hicaznar' reaching around 2578 GDD and followed by 'Katirbasi' and 'Suruc' around 2440-2375. Our results showed the heat requirements for fruit ripening were slightly close to Hicaznar cultivar and it was higher than Katirbasi and Suruc cultivars. This difference highly likely can be due to different climatic conditions of pomegranate grown.

Table 1 - Heat unit accumulated in each sampling time during 2017

\begin{tabular}{ll}
\hline Date & GDD \\
\hline April 26 & $11.85 \pm 1.66$ \\
\hline May 3 & $70.85 \pm 0.62$ \\
\hline May 10 & $158 \pm 0.60$ \\
\hline May14 & $212.9 \pm 0.58$ \\
\hline May 20 & $295.35 \pm 0.40$ \\
\hline May 31 & $491.65 \pm 0.55$ \\
\hline June 10 & $653.20 \pm 0.49$ \\
\hline June 21 & $865.70 \pm 0.49$ \\
\hline July 6 & $1150.17 \pm 0.43$ \\
\hline July 16 & $1341.42 \pm 0.41$ \\
\hline September 6 & $2129.56 \pm 0.27$ \\
\hline September 16 & $2245.96 \pm 0.26$ \\
\hline September 26 & $2343.55 \pm 0.28$ \\
\hline October 5 & $2446.30 \pm 0.27$ \\
\hline October 18 & $2560.95 \pm 0.28$ \\
\hline
\end{tabular}

The results indicate that calyx diameter and length of pomegranate fruit has a slow continues liner growth pattern. As are shown in Figs. 1 and 2, calix diameter and length significantly increased during the growing season.

The reduction process in calyx length and diameter, observed at the early stages of measurement, can be due to the random selection of process. Owing to this fact, that pomegranate trees have two or three flowering peaks, the measurement of second or third series of flowers that are physiologically far behind the first phases showed various diffently in growth pattern. Only selected flowers were measured after May 10 to reduce this error. The maximum calyx length $(25.42 \mathrm{~mm})$ and calyx diameter $(21.58 \mathrm{~mm})$ were recorded on September 6 and 26, respectively. These results were in agreement with the findings of Zarei et al. (2015) and Varasteh et al. (2006) on various pomegranate cultivars. They observed a small change in calyx diameter and length during the growing season. So, calyx length and diameter are formed in the early stages of the growing season and do not change considerably until they mature.

The fruit diameter and length had a same growth pattern during the growing season. Fruit diameter and length continually increased from the first to the end of the growing season (Figs. 3 and 4). The minimum fruit diameter $(9 \mathrm{~mm})$ was observed at first recording dates and when fruits matured, they attained the highest fruit length $(71 \mathrm{~mm})$. At the beginning of growing season, there was a reduction in fruit length until the end of the May that was because of random fruit selection process. Thereafter, fruit began to develop in diameter and length in early June.

The highest fruit length was recorded on October 5 and 10 before harvest. The three stages of this double sigmoid curve are included. Stage one that is cell division. The second stage has a slow growth that coincides with the period of pit hardening. At this stage, the speed of 
mesocarp growth decreased. In the second stage, the development of the embryo ends. In the third stage, due to the increase in the size of the cells and the formation of cellular spaces, the growth rate increases again (Opara, 2000).

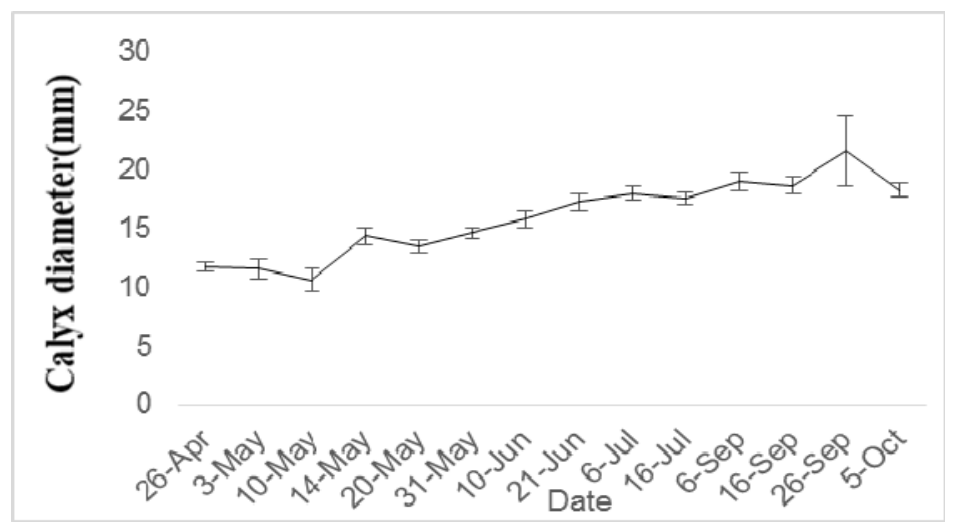

Figure 1 - The changes of calyx diameter during the growing season

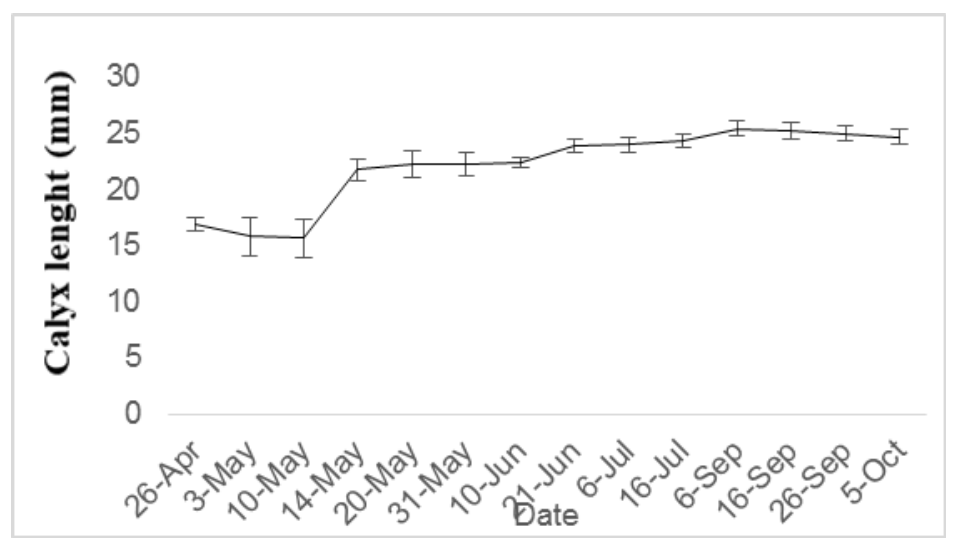

Figure 2 - The changes of calyx length during the growing season

Because of pit hardening after a reduction in development until June 16 , cells started to expansion again and both fruit length and diameter increased. Shulman et al. (1984) suggested the edible juicy tissue of the seeds grew continuously from June to October, whereas the internal stone tissue stopped growing and hardened by the end of June. The length and the diameter of the fruit increased rapidly until 45 days after fruit setting and then continued to increase slowly until the time of fruit harvest (Varasteh et al., 2006). Zarei et al. (2015) reported a linear growth curve in case of pomegranate fruit length and diameter. Also, Al-Yahyai et al. (2009) observed fruit length and diameter continuously increased in 
Qusum, Malasi and Hamedh cultivars during the growing season. Gozlekci and Kaynak (2000) reported a single sigmoid growth curve for pomegranate fruit cv. Hicaznar in terms of fruit diameter and length change. Al-Yahyai et al. (2009) reported that different cultivars might resulted in variable patterns of fruit growth.

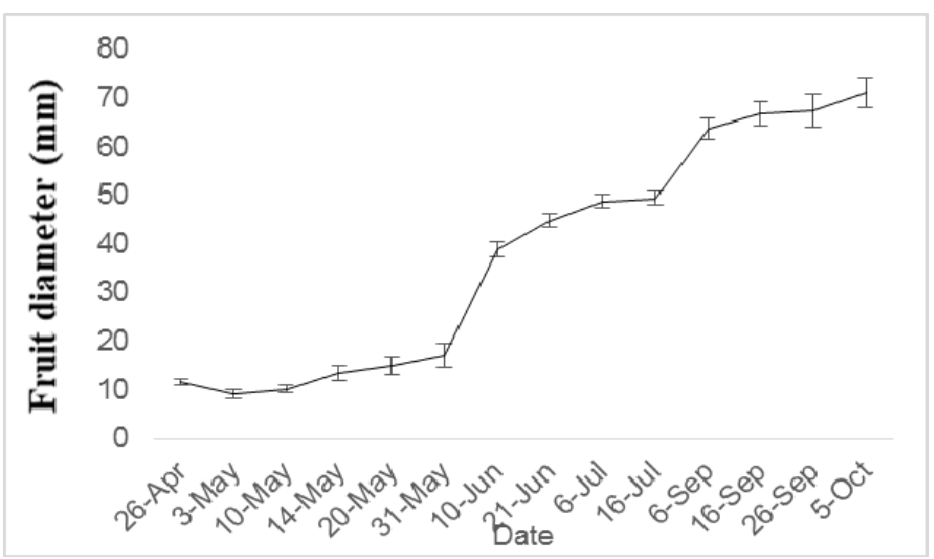

Figure 3 - The changes of fruit diameter during the growing season

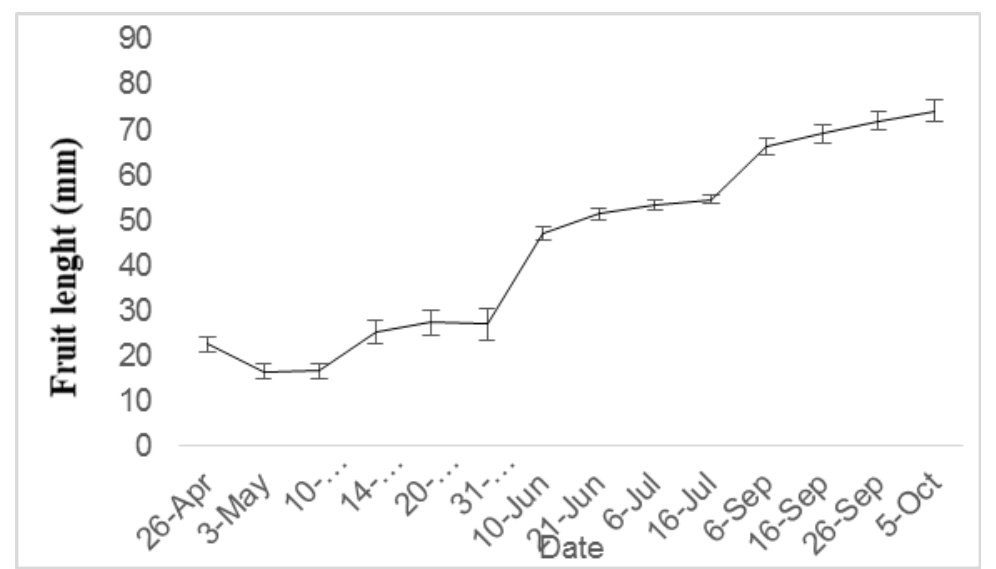

Figure 4 - The changes of fruit length during the growing season

The changes of fruit fresh weight are shown in Fig 5. According to recorded data, fruit fresh weight increased slowly in early growth stages (April 26-June 21) and was not significantly different between early recording dates. It starts to increase faster in June and continued to reach the highest $(252.7 \mathrm{~g})$ in October. Dry weight changes showed a similar trend with fresh weight (Fig. 6). It slowly increased in April to late June. This increase was faster in the next months. On October 5 and September 
26 the highest fruit dry weight $(57 \mathrm{~g})$ was recorded. Chalmers et al. (1983) estimate that $80-82 \%$ of fruit development takes place in the third stage of growth. Fertilized ovary grows in size, consequently increased the fruit weight. Varasteh et al. (2006) reportes similar resultes in pomegranate cv. Malas-e-Torsh-e-Saveh. They reported the average fruit weight increased rapidly until 45 days after fruit setting and then continued more slowly until the time of fruit harvest (Varasteh et al. 2006). Zarei Mohammadabad (2010) reported that increase of fruit weight was faster in the last months of the growing season, compared to the beginning of the season. It is because the fruit enlarges almost to its final size through cell enlargement (Melgarejo et al. 1997). Dry weight is commonly used in growth analysis to reflect the actual amount of new organic material synthesized by the plant or organ. As a consequence of fruit enlargement, fruit fresh and dry weights were increased, as well. The results obtained in some of the previous studies showed establishing reliable equations for predicting fruit weight and fruit volume by measuring fruit dimensions. For instance, strong relationships were reported between fruit diameter, fruit volume and fruit weight in apricot by Arzani et al. (1997). Also, in pears, Ortega et al. (1998) found a correlation between fruit diameter and fruit size.

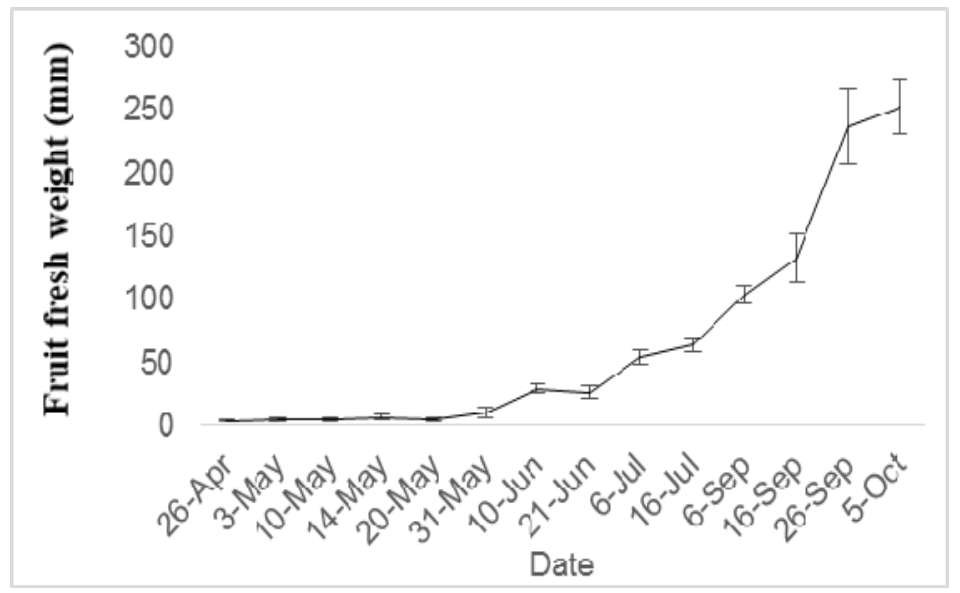

Figure 5 - The changes of fruit fresh weight during the growing season

In current study, the ratio of fruit length to diameter reduced significantly until June 10 , but after that it stayed unchanged. As shown in Figs. 2 and 3, the fruit length was two-fold of the fruit diameter at the beginning of growing season. But, as well as the fruit grows and develop their length and diameter almost equaled. So, the ratio of fruit length to diameter was almost double at the beginning of growing season and then 
it reduced slowly and closed to one (Fig. 7). In this stage, fruits are reached to their final shape, well the nearly round. This was in accord to the findings of Gozlekci and Kaynak (2000). They observed fruits shape were elongated in the beginning and their final shape was nearly round.
Because fruits are getting massive, hence this ratio is a decreasing process (Zarei et al., 2015). Similarly, some author reported that with the growth of apple, pear and peach fruit, the length to diameter fruit ratio decreases rapidly (Maib, 1996).

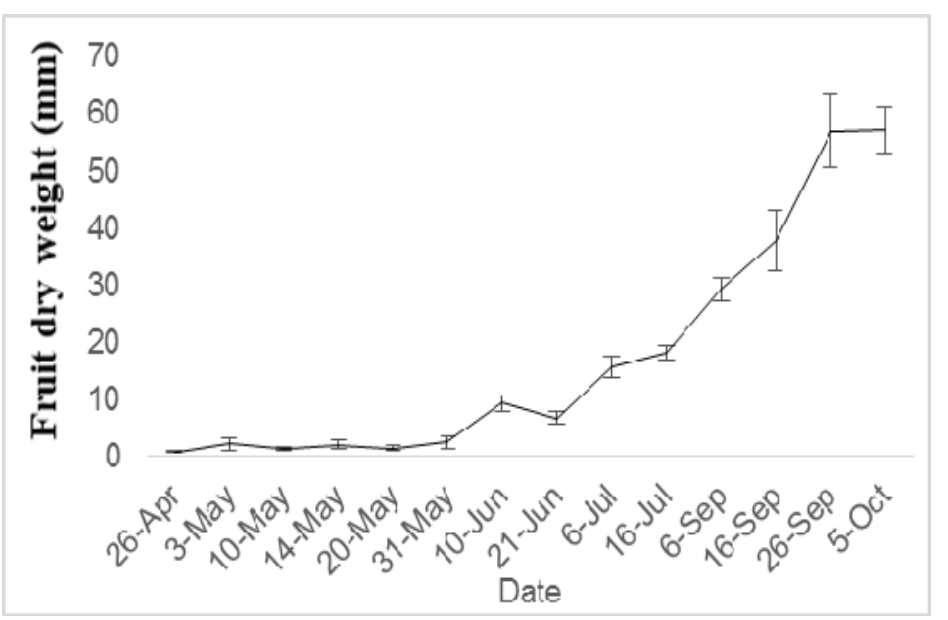

Figure 6 - The changes of fruit dry weight during the growing season

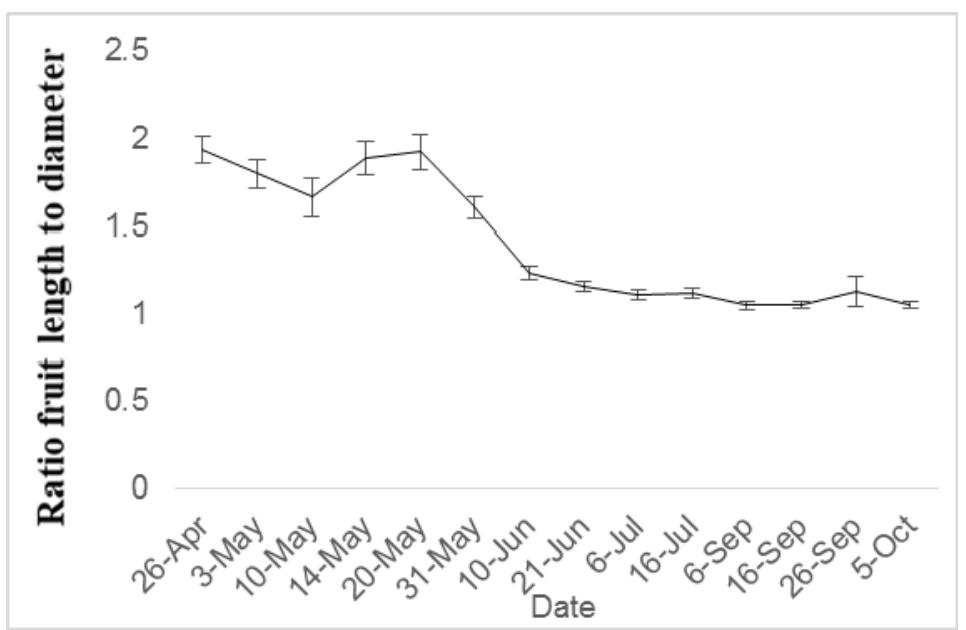

Figure 7 - The ratio of fruit length to diameter 


\section{CONCLUSIONS}

Few published data on the characteristics of Shishe-Kab cultivar in the literature is available. Based on the results of this study, it was determined that the maturity and fruit size are affected by the temperature. The study of fruit length and diameter exhibited a double sigmoid growth curve, while the fresh and dry weight followed a single sigmoidal curve. To determine the growth pattern of Shishe-Kab cultivar in addition to physical measurements, biochemical and microstructural measurements would be needed. By determining the fruit growth pattern under climatic conditions, a more accurate harvesting date can be estimated. It is also possible to determine the length of growing season and the critical stages of growth for proper management in the garden.

\section{REFERENCES}

Al-Yahyai, R., Al-Said, F. \& Opara, L. (2009). Fruit growth characteristics of four pomegranate cultivars from northern Oman. Fruits, 64(6): 33541, DOli: 10.1051/fruits/2009029.

Arzani, K., Lawes, S. \& Wood, D. (1997). Estimation of 'Sundrop' apricot fruit volume and fresh weight from fruit diameter. Acta Hortic., 488: 321-326, DOI: $10.17660 /$ ActaHortic. 1999.48 8.50

Arzani, K. (1994). Horticultural and physiological aspects of vigour control in apricot (Prunus armeniaca L.) under orchard and controlled environment conditions. Auckland,
New Zealand, Massey University, Ph.D. Dissertation.

Barati, Z. (2017). Evaluation of yield, biochemical and medicinal characteristics of seedless barberry fruit (Berberis vulgaris L.) under different regins of Southern Khorasan regarding to heat unit perception. Birjand, Iran, University of Birjand, Master's thesis.

Bleiholder, H., Van den Boom, T., Langelüddecke, P. \& Stauss, R. (1989). Einheitliche Codierung der phänologischen Stadien bei Kultur-und Schadpflanzen. Gesunde Pflanzen, 41(11): 381-384.

Candir, E.E., Ozdemir, A.E., Kaplankiran, T. \& Toplu, C. (2009). Physico-chemical changes during growth of persimmon fruits in the East Mediterranean climate region. Sci.Hortic., 121(1): 42-48, DOI: 10.1016/j.scienta.2009.01.009.

Cangi, R., Şen, A. \& Kılıç, D. (2008). Determination of phonological characters and effective heat summations required for maturation of some grapes cultivars grown in Kazova Region (Tokat-Turhal). Res. J.Agric. Sci., 1(2): 45-48.

Chalmers, D.J., Olsson, K.A. \& Jones, T.R. (1983). Water relations of peach trees and orchards. In: Water deficits and plant growth (T.T. Koslowski, ed.), 7: 197-232, Academic Press, New York.

Ebtedaei, M. \& Shekafandhe, A. (2016). Morpho-physiological changes of two cultivars of pomegranate 'Rabab' and 'Shisheh Gap' under water stress conditions. Iranian J. Hortic. Sci. 17(2): 209-220.

Egea, J., Ortega, E., Martínez-Gómez, P. \& Dicenta, F. (2003). Chilling and heat requirements of almond cultivars for flowering. Environ. Exp. Bot., 50(1): 79-85, DOI: 10.1016/S00 98-8472(03)00002-9.

Génard, M. \& Bruchou, C. (1993). A functional and exploratory approach to studying growth: the example of 


\section{HEAT REQUIREMENT OF POMEGRANATE FRUIT: A CASE STUDY ON SHISHE-KAB CULTIVAR}

the peach fruit. J.Am.Soc.Hortic.Sci., 118(2): 317-23, DOI: 10.21273/ JASHS.118.2.317

Gozlekci, S. \& Kaynak, L. (2000). Physical and chemical changes during fruit development and flowering in pomegranate (Punica granatum L.) cultivar Hicaznar grown in Antalya region. Options Méditerranéennes, Série A, Séminaires Méditerranéens, 42: 7985.

Holland, D., Hatib, K. \& Bar-Ya'akov, I. (2009). Pomegranate: botany, horticulture, breeding. Hortic.Rev., 35: 127-91.

Ikinci, A., Mamay, M., Unlu, L., Bolat, I. \& Ercisli, S. (2014). Determination of heat requirements and effective heat summations of some pomegranate cultivars grown in Southern Anatolia. ErwerbsObstbau, 56(4): 131-138, DOI: 10.1007/s10341-014-0220-8

Jackson, D. (1999b). Climate and fruit plants. In: Jackson, D.I. and N.E. Looney (Eds.) Temperate and Subtropical Fruit Production. $2^{\text {nd }}$ edition, CABI Publishing, New York, U.S., pp. 7-14

Jalikop, S.H. (2007). Linked dominant alleles or inter-locus interaction results in a major shift in pomegranate fruit acidity of 'Ganesh'×'Kabul Yellow'. Euphytica, 158(1-2): 201-207.

Korkmaz, N., Askin, M.A., Ercisli, S. \& Okatan, V. (2016). Foliar application of calcium nitrate, boric acid and gibberellic acid affects yield and quality of pomegranate (Punica granatum L.). Acta Sci.Pol.-Hortoru, 15(3): 105-112.

Kumar, K., Pinder, R., Jitender, Dabas, S.T.K. Suraj, Yadav, B. \& Rana, S. (2017). Effect of growth regulators and micronutrients on fruit cracking and fruit yield in pomegranate. Indian J.Agric.Res., 51(3): 272-276.

Luedeling, E., Zhang, M., Luedeling, V. \& Girvetz, E.H. (2009). Sensitivity of winter chill models for fruit and nut trees to climatic changes expected in California's Central Valley. Agric.Ecosyst.Environ., 133(1-2): 2331, DOI: 10.1016/j.agee.2009.04. 016.

Maib, K.M., Andrews, P.K., Lang, G.A. \& Mullinix, K. (eds.) (1996). Tree fruit physiology: growth and development: a comprehensive manual for regulating deciduous tree fruit growth and development. Good Fruit Grower, Yakima, Washington.

Mounzer, O.H., Conejero, W., Nicolás, E., Abrisqueta, I., García-Orellana, Y.V., Tapia, L.M., Vera, J., Abrisqueta, J.M. \& del Carmen Ruiz-Sánchez, M. (2008). Growth pattern and phenological stages of early-maturing peach trees under a Mediterranean climate. HortSci., 43(6): 1813-1818, DOI: 10.21273/ HORTSCI.43.6.1813.

Martinez, J.J., Melgarejo, P., Hernández, F., Salazar, D.M. \& Martinez, R. (2006). Seed characterisation of five new pomegranate (Punica granatum L.) varieties. Sci.Hortic., DOI: 10.1016/j. scienta.2006.07.018.

Melgarejo, P., Martínez-Valero, R., Guillamón, J.M., Miró, M. \& Amorós, A. (1997). Phenological stages of the pomegranate tree (Punka granatum L.). Ann.Appl.Biol., 130(1): 135-40, DOI: 10.1111/j.17 44-7348.1997.tb05789.x.

Moing, A., Svanella, L., Rolin, D., Gaudillère, M., Gaudillère, J.P. \& Monet, R. (1998). Compositional changes during the fruit development of two peach cultivars differing in juice acidity. J.Amer. Soc.Hort.Sci., 123(5): 770-775.

Moosavi, S., Arzani, K. \& Alizadeh, S. (2009). Seasonal vegetative and fruit growth patterns of some Asian pear (Pyrus serotina Rehd.) cultivars under Tehran climatic conditions. IJHST, 10(1); 71-84.

Mowat, A.D., George, A.P. \& Collins, R.J. (1996). Macro-climatic effects on fruit development and maturity of 


\section{MOHAMMADIAN MOGHADDAM, F. MORADINEZHAD, M. KHAYYAT}

non-astringent persimmon

(Diospyros kaki L. cv. Fuyu). Acta Hortic., 436: 195-202, DOI: 10.17 660/ActaHortic.1997.436.22.

Nunes, C., Rato, A.E, Barros, A.S, Saraiva, J.A. \& Coimbra, M.A. (2009). Search for suitable maturation parameters to define the harvest maturity of plums (Prunus domestica L.): a case study of candied plums. Food Chem., 112(3): 570-574, DOI: 10.1016/j.foodchem. 2008.06.007.

Opara, L.U. (2000). Fruit growth measurement and analysis. Hortic.Rev., 24: 373-431.

Ortega, S., Fuentes, S. \& Retamales, J.B. (1997). Models for predicting fruit diameter of Packham's Triumph pears. VII International Symposium on Pear Growing, 475: 295-302, DOI: $10.17660 /$ ActaHortic.1998.475. 35.

Özkan, M. (2002). Degradation of anthocyanins in sour cherry and pomegranate juices by hydrogen peroxide in the presence of added ascorbic acid. Food Chem., 78(4): 499-504, DOI: 10.1016/S0308-8146 (02)00165-6.

Pekmezci, M. \& Erkan, M. (2003). Pomegranate postharvest quality maintenance guidelines. USDA, Agricultural Research Services. Agriculture Handbook, 66.

Qashqai, A., Farzan, E. \& Majd, D. (2017). Investigating phylogenic growth stages of kiwi cultivar Hayward in western Guilan. J. Plant Prod.Res., 23(4): 97-116.

Rajasekar, D., Akoh, C.C, Martino, K.G. \& Maclean, D.D. (2012). Physicochemical characteristics of juice extracted by blender and mechanical press from pomegranate cultivars grown in Georgia. Food Chem., 133(4): 1383-1393. DOI: 10.1016/j. foodchem.2012.02.025.

Rea, R. \& Eccel, E. (2006). Phenological models for blooming of apple in a mountainous region. Int.J.
Biometeorol., 51(1): 1-6, DOI: 10.10 07/s00484-006-0043-x.

Richardson, E.A., Seeley, S.D., Walker, D.R., Anderson, J.L. \& Ashcroft, G.L. (1975). Pheno-climatography of spring peach bud development. HortSci., 10: 236-237.

Schaffer, B. \& Andersen. P.C. (eds.) (1994). Handbook of environmental physiology of fruit crops. Vol. II. Subtropical and tropical crops. CRC Press, Boca Raton, Florida.

Shulman, Y., Fainberstein, L. \& Lavee, S. (1984). Pomegranate fruit development and maturation. J.Hort.Sci., 59(2): 265-274, DOI: 10.1080/00221589.1984.11515196.

Sitte, P., Ziegler, H., Ehrendorfer, F. \& Bresinsky, A. (1999). Lehrbuch der Botanik für Hochschulen, 34. Aufl. Spektrum, Akad. Verl., Heidelberg, ISBN 3-8274-0779-6.

Soloklui, A.A.G., Gharaghani, A., Oraguzie, N., Eshghi, S. \& Vazifeshenas, M. (2017). Chilling and heat requirements of 20 Iranian pomegranate cultivars and their correlations with geographical and climatic parameters, as well as tree and fruit characteristics. HortSci., 52(4), 560-565. DOI: 10.21273/HO RTSCI11614-16.

Valentini, N., Me, G., Ferrero, R. \& Spanna, F. (2001). Use of bioclimatic indexes to characterize phenological phases of apple varieties in Northern Italy. Int.J.Biometeorol., 45(4): 191-195. DOI: $10.1007 / \mathrm{s} 004840100107$.

Varasteh, F., Arzani, K., Zamani, Z. \& Mohseni, A. (2006). Evaluation of the most important fruit characteristics of some commercial pomegranate (Punica granatum L.) cultivars grown in Iran. Acta Hortic., I International Symposium on Pomegranate and Minor Mediterranean Fruits, 818, 103-108. DOI: $10.17660 /$ ActaHortic.2009.818. 13.

Varasteh, F., Arzani, K., Zamani, Z. \& Tabatabaei, S.Z. (2006). Physico- 


\section{HEAT REQUIREMENT OF POMEGRANATE FRUIT: A CASE STUDY ON SHISHE-KAB CULTIVAR}

chemical seasonal changes of pomegranate (Punica granatum L.) fruit "Malas-e-Torsh-e-Saveh" in Iran. Acta Hortic., XXVII International Horticultural Congress, International Symposium on Asian Plants with Unique Horticultural Potential, 769: 255-258, DOI: 10.17660/ActaHortic. 2008.769.36.

Vidal, A., Fallarero, A., Peña, B.R., Medina, M.E., Gra, B., Rivera, F., Gutierrez, Y. \& Vuorela. P.M. (2003). Studies on the toxicity of Punica granatum L. (Punicaceae) whole fruit extracts. J.Ethnopharmacol., 89(2-3): 295300, DOI: 10.1016/j.jep.2003.09. 001.

Weaver, R.J. (1976). Grape growing. John Wiley \& Sons, New York, 371p.

Wert, T.W., Williamson, J.G., Chaparro, J.X., Miller, E.P. \& Rouse, R.E. (2009). The influence of climate on fruit development and quality of four low-chill peach cultivars. Hort.Sci., 44(3): $666-670$, DOI: $10.21273 / \mathrm{HO}$ RTSCI.44.3.666

Wien, H.C. (ed.) (1997). The physiology of vegetable crops. CAB International, New York, pp.479-509.

Zarei, A., Zamani, Z. \& Fatahi, M. (2015). Seasonal changes in fruits of 13 pomegranate (Punica granatum L.) genotypes during developmental stages. First National Conference on Agriculture and Development, Tehran, Iran.

Zarei Mohammadabad, M. (2010). Investigation of physicochemical properties, bioactive compounds and antioxidant activity of different fruit parts of six pomegranate cultivars during development. Mashhad, Iran, Ferdowsi University of Mashhad, Master's thesis. 